\title{
Pionierska eksploracja gór wyrażona poprzez architekturę
}

\author{
Dariusz Kronowski \\ https://orcid.org/0000-0002-5510-2122 \\ dariusz.kronowski@wp.pl \\ Wydziat Architektury i Sztuk Pięknych, Krakowska Akademia im. Andrzeja Frycza Modrzewskiego
}

\begin{abstract}
Maniactwo do gór czy do jakichkolwiek innych zjawisk przyrody niesie człowieka bez widocznej na pozór przyczyny i wydobywa z niego energię i wytrzymałość, jakiej w innym wypadku nie zwykł okazywać...
\end{abstract}

Stanisław Witkiewicz "Na przełęczy. Wrażenia i obrazy z Tatr"

\begin{abstract}
Streszczenie: Opracowanie ma za zadanie uporządkowanie wiedzy nt. rozwoju architektury górskiej. Obejmuje okres czasowy, od powstawania pierwszych schronień, powiązany z pionierskimi odkryciami w dziedzinie architektury i krajobrazu gór. W aspekcie tematycznym podjęto zagadnienia turystyki oraz cech naukowych kształtowania obiektów górskich na wybranych przykładach. Również analizie poddano zagadnienia z dziedziny konstrukcji oraz wykorzystania materiałów rodzimych w zależności od lokalizacji, a także takich czynników jak klimat i tradycja miejsca. Podkreślono również znaczenie przyrody oraz próbę odpowiedzi, jak kształtować architekturę górską, nie ingerując w środowisko naturalne oraz wiązać ze sobą przyrodę i budowlę. Wskazano również różnice występujące $w$ formach architektonicznych, a także zakres wpływu odmienności kulturowej i czerpania z wzorców.

Podczas analizy tematu autor studiował i zebrał materiały związane bezpośrednio i pośrednio z tematem. Zostały przeanalizowane wymienione w tekście dzieła architektury górskiej, a także ich historia i rozwój dziejowy. Przedstawiono analizę materiału na podstawie problematyki obejmującej przekrój opracowania, a także ważnych zakresów tematycznych, terytorialnych i czasowych charakteryzujących poszczególne etapy rozwoju architektury górskiej od początków istnienia zbadanych budowli górskich ukształtowanych przez kulturę zbieractwa i pasterstwa do analizy szczegółowej opracowanej na podstawie architektury górskiej XIX i XX wieku.

Najpierw było drewno, kamienie, ziemia - podstawowe budulce. Architektura górska to obiekty często wymagające, monumentalne o kształcie charakterystycznym dla formy terenu, mniej dla natury regionalnej, chociaż z niej się wywodzące, ale również obiekty tworzące naturę i charakter miejsca tzw. "genius loci". Poszukiwanie fantazji, a także niepowtarzalnego piękna - wszystko to świadczy, że górska architektura nie jest tylko rzemiosłem o wąsko zakreślonych granicach, ale sztuką lekką, twórczą i nieskrępowaną. W dzisiejszym kształtowaniu architektury krajobrazu górskiego ważne jest oparcie na wiedzy historycznej. W kontraście świadomym bryła poddana jest porządkowi, czyli przeciwieństwu chaosu, zapanowaniu nad ładem na krawędzi w procesie projektowym. W budynkach, które charakteryzuje kontrast w stosunku do otoczenia - geometria i forma, a także struktura jest drogą do nieprzypadkowej architektury w trudnych warunkach. Architektury ukrytej w terenie, introwersyjnej, zamkniętej w świecie uwalniającym odbiorcę od panującego, na co dzień nieporządku. Jest to czysta pionierska twórczość architektów bez architektury tworzących obiekty od naśladownictwa jak np. szałasy oraz typowe schrony górskie oparte o czysty regionalizm.

W architekturze górskiej można wymienić trzy zasadnicze odmiany, różniące się pod względem twórczego podejścia:

- architektura od naśladownictwa - mimesis - zasada twórczego naśladownictwa,

- architektura - harmoniczna, nawiązująca, ale niepowtarzająca wzorców,

- architektura w kontraście świadomym.
\end{abstract}

Słowa kluczowe: architektura górska, Tatry, Zakopane, Kuźnice, szałas góralski, miasteczko 


\section{Pasterstwo}

W Tatrach sezonowy letni budynek pasterzy nazywano salaš . Innym określeniem częściej stosowanym był košiar. Nazwy te są używane w rejonie hal słowackich i oznaczają pasterskie gospodarstwo owcze. Należy zwrócić uwagę na wyraźnie widoczne różnice pomiędzy kulturą pasterską a rolną - pierwsza z nich jest, bowiem kulturą ruchomą i dynamiczną, druga natomiast statyczną.

Pasterstwo jest typem gospodarki związanej z letnim wypasem owiec na halach. W lecie stado owiec zebrane od różnych właścicieli jest prowadzone pod opieką bacy oraz juhasów na pastwiska górskie. Tam też przez okres lata pasterze mieszkają w szałasach.

Błędem jest nieprawidłowe określanie zabudowy i używanie terminu szałas w nazewnictwie obiektów związanych z wszelką sezonową gospodarką pasterską lub sianokośną w rejonach górskich. Budynki niemające żadnego związku z wypasem owiec należy nazywać szopami, nie szałasami, kolebami czy bacówkami. Szopy² mają, bowiem niejednorodną architekturę, różnią się od szałasów zarówno formą bryły, jak i zagospodarowaniem funkcji wnętrza.

$\mathrm{Na}$ halach tatrzańskich często spotyka się też szałasiska ${ }^{3}$. W gwarze podhalańskiej nazwy sałasiska oraz szałasisko oznaczają miejsce, gdzie niegdyś stał pasterski szałas lub zespół szałasów. Występują one w całym paśmie Karpat. Interesujące zespoły można napotkać, wędrując w paśmie Gorczańskiego Parku Narodowego w rejonach Turbacza.

W Tatrach Słowackich podobne znaczenie ma słowo koszarzysko, w gwarze słowackiej określane, jako kosarzýsko lub košarisko. Terminy te występują w wielu nazwach tatrzańskich oraz w pierwotnej terminologii ludowej, np. Jarząbcze Szałasiska czy Sołtysie Szałasiska. Przykładem tego typu zabudowy są Szałasiska, wznoszące się od 1340 do 1390 m n.p.m., nazywane inaczej Stare Szałasiska lub błędnie Włosienica. Jest to śródleśne pochyłe wzniesienie, gdzie dawniej rozlegle były rozmieszczone szałasy pasterskie. Rejon ten widoczny jest po zachodniej stronie szosy w odległości 1,5 km do Morskiego Oka, u stóp wschodnich stoków Opalonego, a nieco na południowy zachód od Włosienicy. Od wielu lat na Szałasiskach znajduje się obozowisko dla taterników Polskiego Związku Alpinizmu.

Ciekawym zagadnieniem jest gwarowa wymowa słowa szałas na Podtatrzu Polskim. Tatrzańscy górale słowo szałas wymawiają salas, a pochodzi ono z węgierskiego słowa szállás, oznaczającego nocleg.

\section{Szałasy}

Ważnym, „inteligenckim podbojem" Tatr były badania naukowe, wywodzące się, co najmniej od Stanisława Staszica, poświęcone architekturze górskiej. W tej mierze najbardziej wyrazistym kształtem dla danego regionu górskiego była bryła szałasu pasterskiego, którego strome lub płaskie dachy i ciekawe kształty stały się inspiracją dla wielu schronisk górskich na świecie, w tym również w Polsce.

Dotychczas przeprowadzono wiele badań nad formą szałasu pasterskiego. Wśród ważniejszych publikacji, do których można się w tej dziedzinie odnieść, znajduje się studium architektoniczno-budowlane autorstwa Rudolfa Śmiałowskiego ${ }^{4}$ (dziekan i profesor WA PK w latach 1948-1951), określające w sposób pionierski formy istniejących szałasów.

Dzięki tej pracy oraz dołączonym do niej opracowaniom etnograficzno-geograficznym, głównie pochodzącym ze szkoły profesora Romana Reinfussa, można zrekonstruować formy szałaśnictwa oraz typ osadnictwa w polskiej części Tatr.

Dalsze, wybitne badania architektoniczne nad formą szałasu pasterskiego prowadzone były również na przełomie lat pięćdziesiątych i sześćdziesiątych przez Tadeusza Przemysława Szafera ${ }^{5}$. W późniejszych latach profesor kierował Pracownią Regionalną Politechniki Krakowskiej w Zakopanem, która badała przydatność

\footnotetext{
Por. Z. Radwańska-Paryska, W.H. Paryski, Wielka encyklopedia tatrzańska, wyd. „Wydawnictwo Górskie”, Poronin 1995, s. 1179. Ibidem.

Por. Z. Radwańska-Paryska, W. H. Paryski, op. cit., s. 1179.

Por. R. Śmiałowski, Architektura i budownictwo pasterskie w Tatrach Polskich, PWN, Kraków 1959.

Por. T. P. Szafer, Tatrzańskie szałasy pasterskie, Wydawnictwo Zakład Historii Urbanistyki i Architektury PAN, Warszawa 1961, s. 9-12.
} 
oraz skuteczność nowych technologii budowlanych i rozwiązań przestrzennych w architekturze ziem górskich na podstawie zastosowań konstrukcyjnych, związanych z szałasami pasterskimi. Jednym z kierunków działań pracowni w latach dziewięćdziesiątych było pielęgnowanie tradycji i utrwalanie doświadczeń mieszkańców regionu Podhala w dziedzinie sztuki budowlanej.
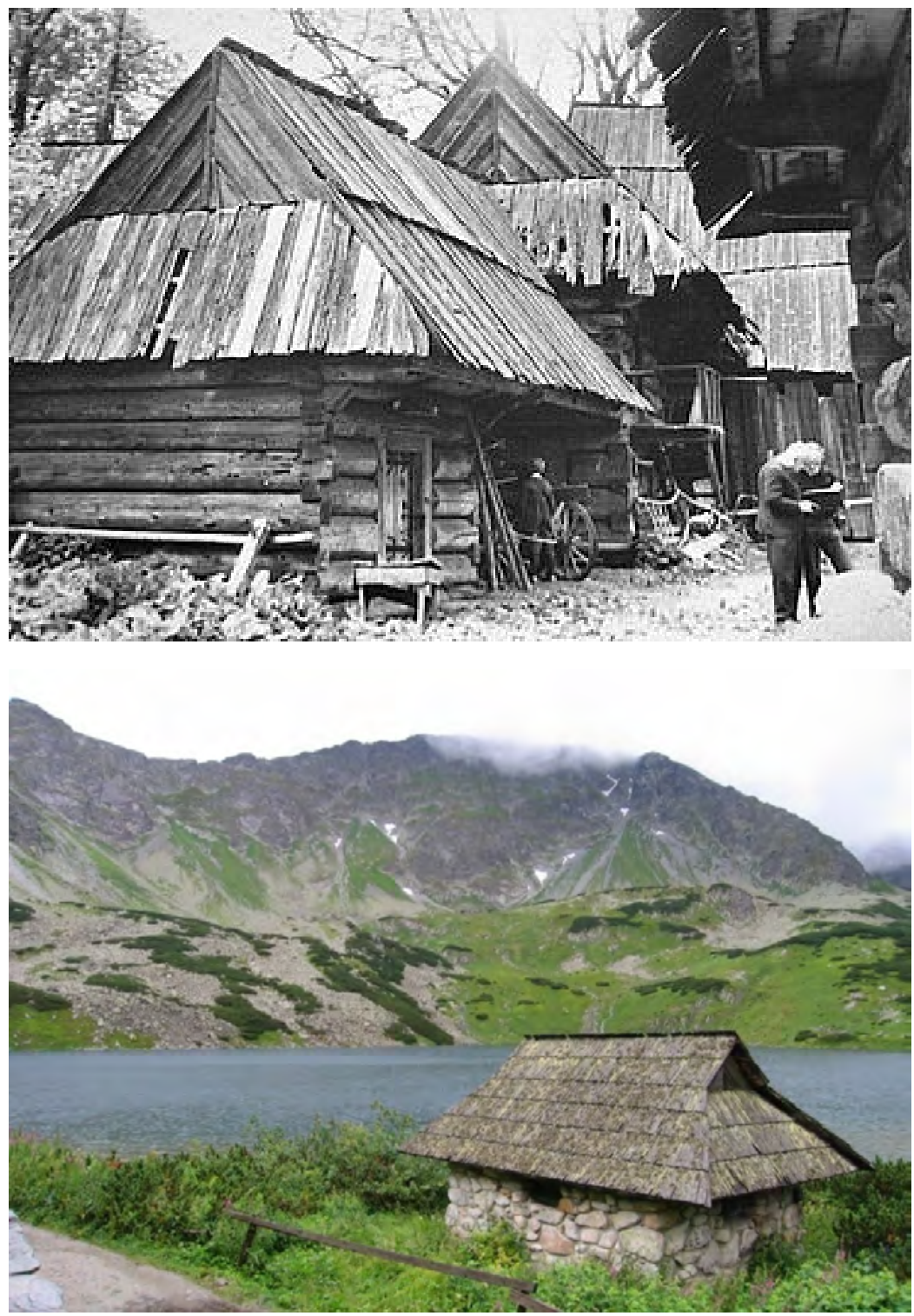

Ryc. 1. Profesor Rudolf Śmiałowski w trakcie pomiarów w Chochołowie. Archiwum Politechniki Krakowskiej

Fig.1. Professor Rudolf Śmiałowski during measurements in Chochołów. Archives of the Cracow University of Technology
Ryc. 2. Tatry Polskie. Dolina Pięciu Stawów Polskich. Szałas pasterski, fot. Autor, 2004 rok

Fig. 2. Polish Tatras. The Valley of the Five Polish Ponds. Shepherd's hut, photo author, year 2004

Jednak do tej pory nie przeprowadzono gruntownych badań struktury ustrojów konstrukcyjnych i etapów ich ewolucji, zmierzającej od prymitywnych schronów do doskonalszej formy bacówki (a po niej schroniska), która uzyskała nobilitację w propagowanym przez Stanisława Witkiewicza - stylu zakopiańskim ${ }^{6}$. Jego kreator dopatrywał się w góralskich chatach i szałasach cech budownictwa drewnianego z czasów Kazimierza Wielkiego $^{7}$. Styl zakopiański stać się miał, zatem - według Witkiewicza - zarzewiem polskiej architektury w sytuacji zagrożeń rozbiorowych. 

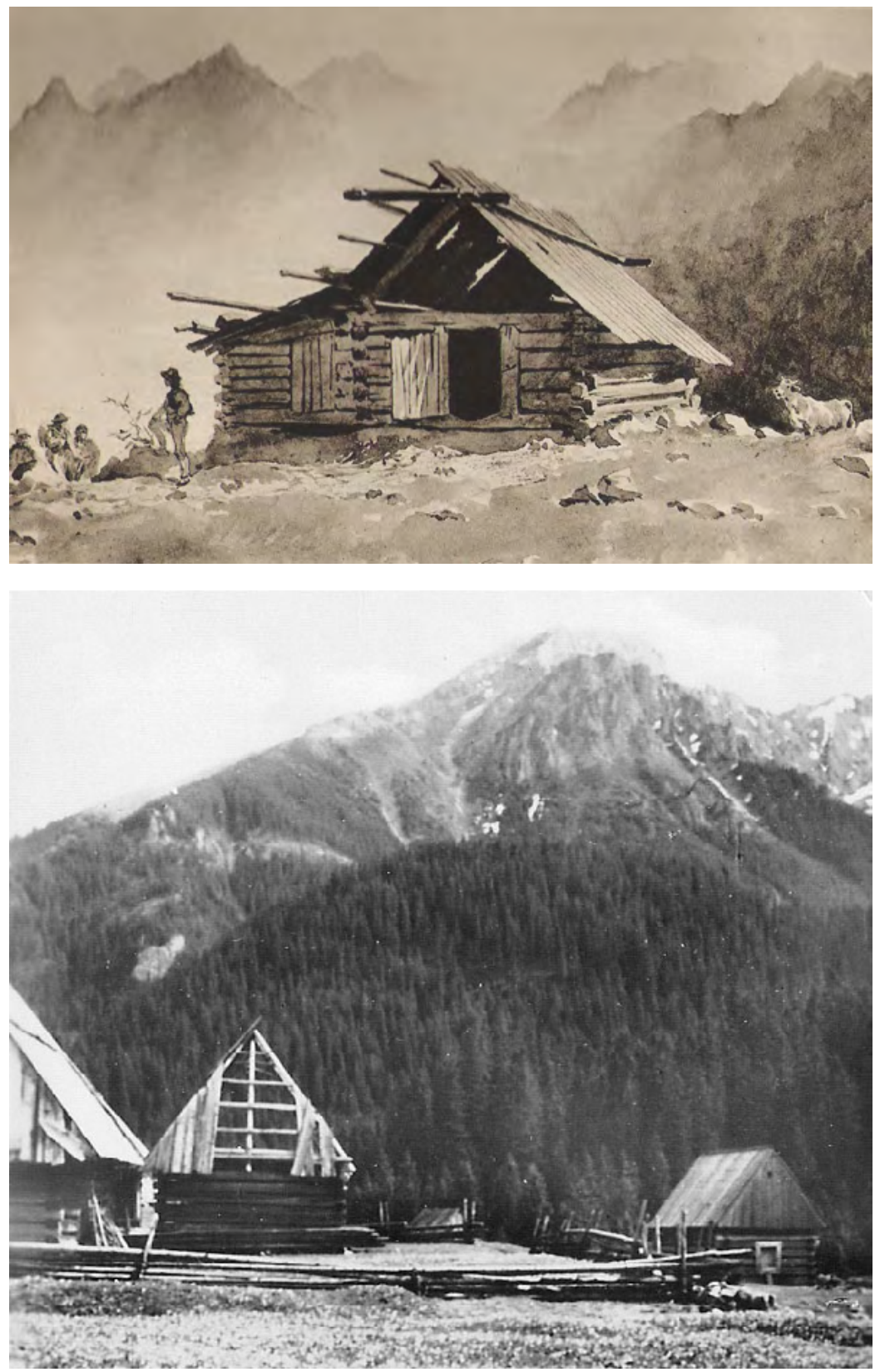

Ryc. 3. Tatry Polskie. Szałas w Tatrach. Obraz Walerego Eljasza. Źródło: Walery Goetel, Zagadnienia regionalizmu górskiego $\mathrm{w}$ Polsce, Wydawnictwo Związku Ziem Górskich, Kraków 1936, s. 1

Fig. 3. Polish Tatras. A hut in the Tatras. Picture of Valery Elias. Source: Walery Goetel, The issues of mountain regionalism in Poland, Publishing House of the Union of Lands Górskich, Krakow 1936, p. 1
Ryc. 4. Tatry Polskie. Dolina Chochołowska. Szałasy pasterskie,fot. Józef Oppenheim, 1948 rok. Źródło: Archiwum autora

Fig. 4. Polish Tatras. Chochołowska Valley. Shepherd's huts, photo. Józef Oppenheim, 1948. Source: author's archive

Charakterystycznym wzorem szałasu jest budynek koleby w Dolinie Pięciu Stawów Polskich ${ }^{8}$. Przypuszczalnie pochodzi z XVII w. Obiekt usytuowany na wysokości 1671 m n.p.m. jest w tej kategorii najstarszym zachowanym do dziś. Korzystna lokalizacja pozwoliła na wzniesienie budowli doskonale wkomponowanej w otoczenie. Usytuowanie szałasu na szlaku prowadzącym do Morskiego Oka wpłynęło na jego intensywne przeobrażenia, przy czym przyjmuje się, że jego obecny kształt nie odbiega od stanu pierwotnego.

Istotne zmiany - spowodowane wpływami budownictwa stałego na początku XX wieku - upodobniły kształty szałasów do form współczesnych, tworząc z nich jednocześnie wielosezonowe obiekty. Szczególnymi i ważnymi elementami szałasów jest materiał oraz konstrukcja. W latach 1945-1955 wiele wartościowych obiektów szałasowych zostało utraconych bezpowrotnie dla historii architektury. Zostały one zniszczone lub przebudowane. 
Takimi szałasami były; szałas na Hali Kondratowej ${ }^{9}$, który został rozebrany oraz szałas na Polanie pod Wołoszynem, prawdopodobnie spalony w 1948 roku.

Większość budynków rozebrano, ulegały zniszczeniu w wyniku braku konserwacji, jak na przykład obiekty z Doliny Kościeliskiej czy Polany Chochołowskiej lub przerabiano je poprzez szalowanie ścian deskami oraz dodatkowe wycinanie okien. O degradacji i przeróbce naturalnych dóbr kulturowych pisano od dawna. Autorem tekstów był m.in. Walery Eljasz ${ }^{10}$. Cel jest zawsze ten sam i dotyczy warunków stwarzających nowe potrzeby, dla których poświęca się wartości historyczne zawarte w regionalnym budownictwie. Pierwsze szałasy w Karpatach były prymitywnymi, drewnianymi budynkami ${ }^{11}$. Rzadziej, jako budulec stosowało się kamień. Uzależnione to było od położenia obiektu i dostępności materiału.
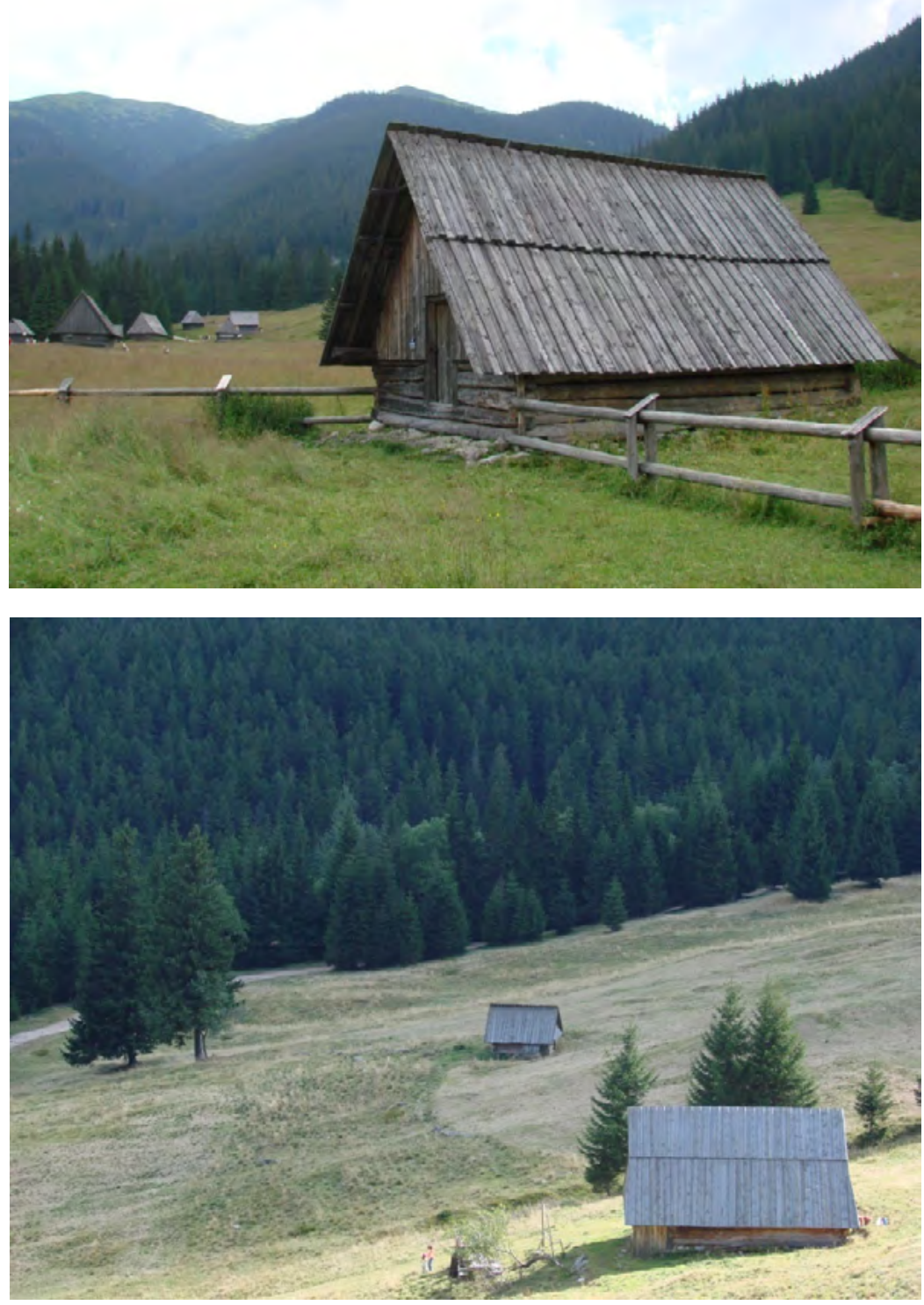

Ryc. 5. Tatry Polskie. Zespół zabytkowych szałasów w Dolinie Chochołowskiej, podlegających ochronie na mocy ustawy z dnia 15 lutego 1962 roku, fot. Autor, 2014 rok

Fig. 5. Polish Tatras. A complex of historic huts in the Chochołowska Valley, protected under the Act of February 15, 1962, photo: author, year 2014

Ryc. 6. Tatry Polskie. Dolina Bystrej. Szałasy w Tatrach pokryte dranicami, fot. Autor, 2007 rok

Fig. 6. Polish Tatras. Bystra Valley. Shelters in the Tatra Mountains covered with dranice, photo: author, year 2007 
Podstawowym budulcem był świerk górski, zwany „smrekiem”. Drewno pozbawiane było kory i w zależności od potrzeby cięte na tzw. płazy, czyli połówki okrąglaków. Kamień używany do budowy był "dziki" i stosowano go w niewielkich ilościach na podpory - fundamenty węgłów ścian budynków oraz na watrzysko, tzn. miejsce na palenisko. Drzewo do budowy pobierano z otaczających hale lub polany lasów, a kamień ze stoków gór, żlebów oraz z potoków.

Ściany szałasów wykonywano z belek poziomych, wiązanych w węgłach "na zamek" tak, że belki jednej ściany były przesunięte w pionie o połowę swej grubości w stosunku do drugiej ściany przyległej. Ścianę budowaną tym systemem nazywa się ścianą węgłową. Wytrzymałość na parcie wiatru ściany węgłowej jest bardzo duża, dlatego stosuje się ją też przy budowie w rejonach wysokogórskich. Poszczególne belki są ze sobą wzajemnie powiązane od dołu do góry.

Zgodnie z faktyczną kolejnością wykonania ściany, zarówno w budowie szałasów, jak i innych obiektów architektonicznych, konstruuje się ją od dołu do góry.

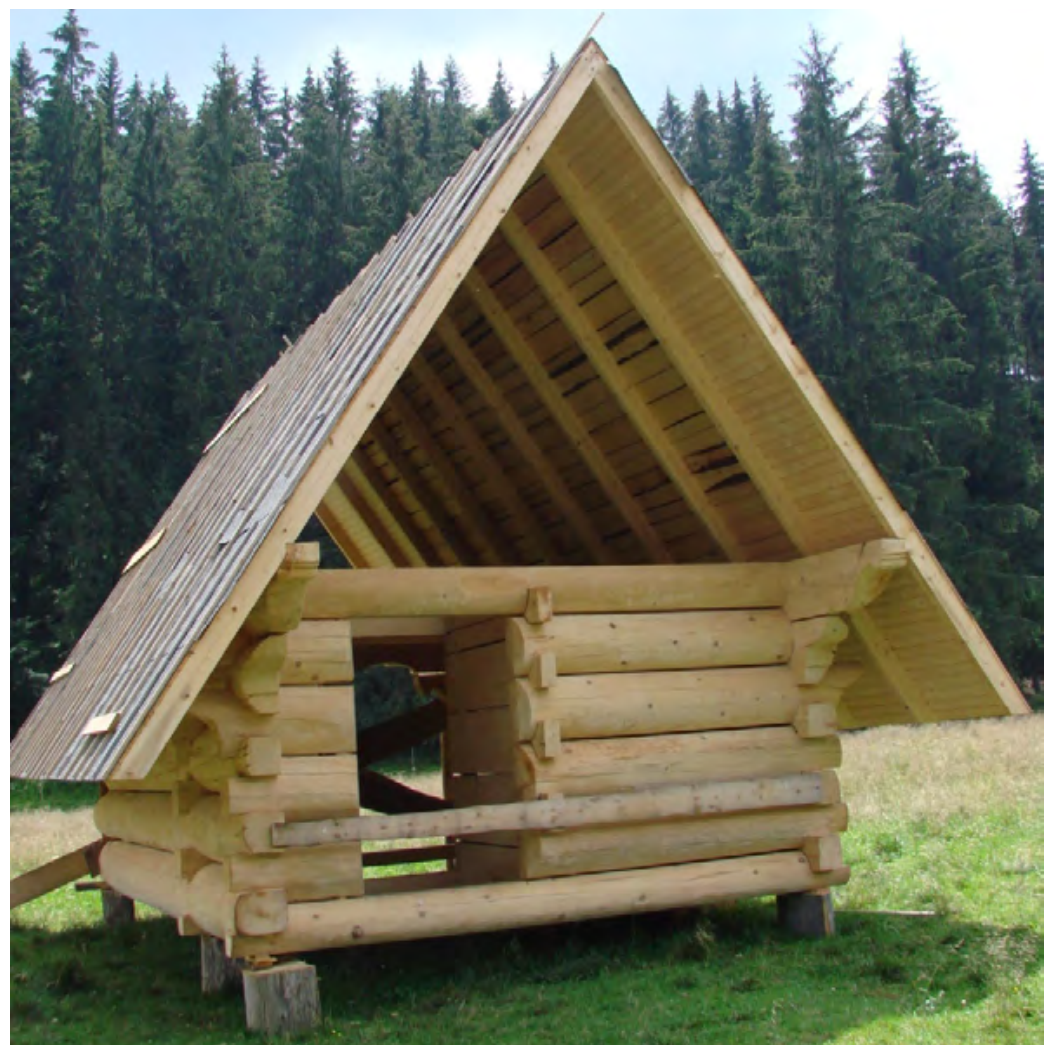

Ryc. 7. Tatry Polskie. Dolina Chochołowska. Współczesny szałas pasterski, budowany wg tradycyjnej metody, przy drodze do Doliny Chochołowskiej, fot. Autor, 2014 rok

Fig. 7. Polish Tatras. Chochołowska Valley. A modern shepherd's hut, built according to traditional method, by the road to the Chochołowska Valley, photo: author, year 2014

Na podstawie badań, jakich dokonał Rudolf Śmiałowski ${ }^{12}$ oraz rozmów przeprowadzonych przez autora z mieszkańcami Podhala dowiedziono, że belki układano na kamieniach, czyli jak mówią górale na „peckach”. Dwa pierwsze elementy ścian, które układano, to belka progowa oraz belka przeciwległa, zwana przez górali "pierwsze drzewo", które stanowią pierwsze elementy poprzecznych ścian szałasu. Na nich układano elementy podłużne, a następnie poprzeczne na zrąb. Taka metoda budowania tłumaczy przemieszczenie belek o połowę grubości. Jak dawna jest zasada tej konstrukcji można przeczytać już u Witruwiusza ${ }^{13}$. Tekst obrazuje wiekowość

13 Por. Witruwiusz, O architekturze ksiąg dziesięć, wyd. Pruszyński i spółka, Warszawa 2004, księga II, rozdział I, s. 47, „... U ludu kolchijskiego nad Morzem Czarnym, wykorzystując obfitość lasów, układa się na ziemi poziomo, na prawo i lewo, ścięte drzewa w takiej od siebie odległości, na jaką pozwala ich długość, a na ich krańcach kładzie się następnie w poprzek dwa inne drzewa; te cztery pnie zamykają przestrzeń przeznaczoną na mieszkanie. Następnie kładzie się na przemian po czterech stronach belki łącząc nimi narożniki budowli i tak stawiając ściany z drewna, wznosi się od dołu do góry pionowe wieże. Szpary, jakie powstają z powodu grubości budulca, zatyka się szczapkami i gliną. Następnie wznosi się dach, obcinając na końcu poprzeczne belki i stopniowo je ściągając; i w ten sposób buduje się nad środkiem budowli piramidę, pokrywając ją liśćmi i gliną i tworzy dachy wieżowe sklepione na sposób pierwotny[...]". 
stosowanej konstrukcji oraz przekazywaną przez pokolenia wiedzę na temat wytrzymałości materiałów oraz odporności zastosowanego budulca już w pierwotnych obiektach, które są nieobce współczesnej architekturze oraz technice budowlanej rozwijanej i modyfikowanej przez wieki.

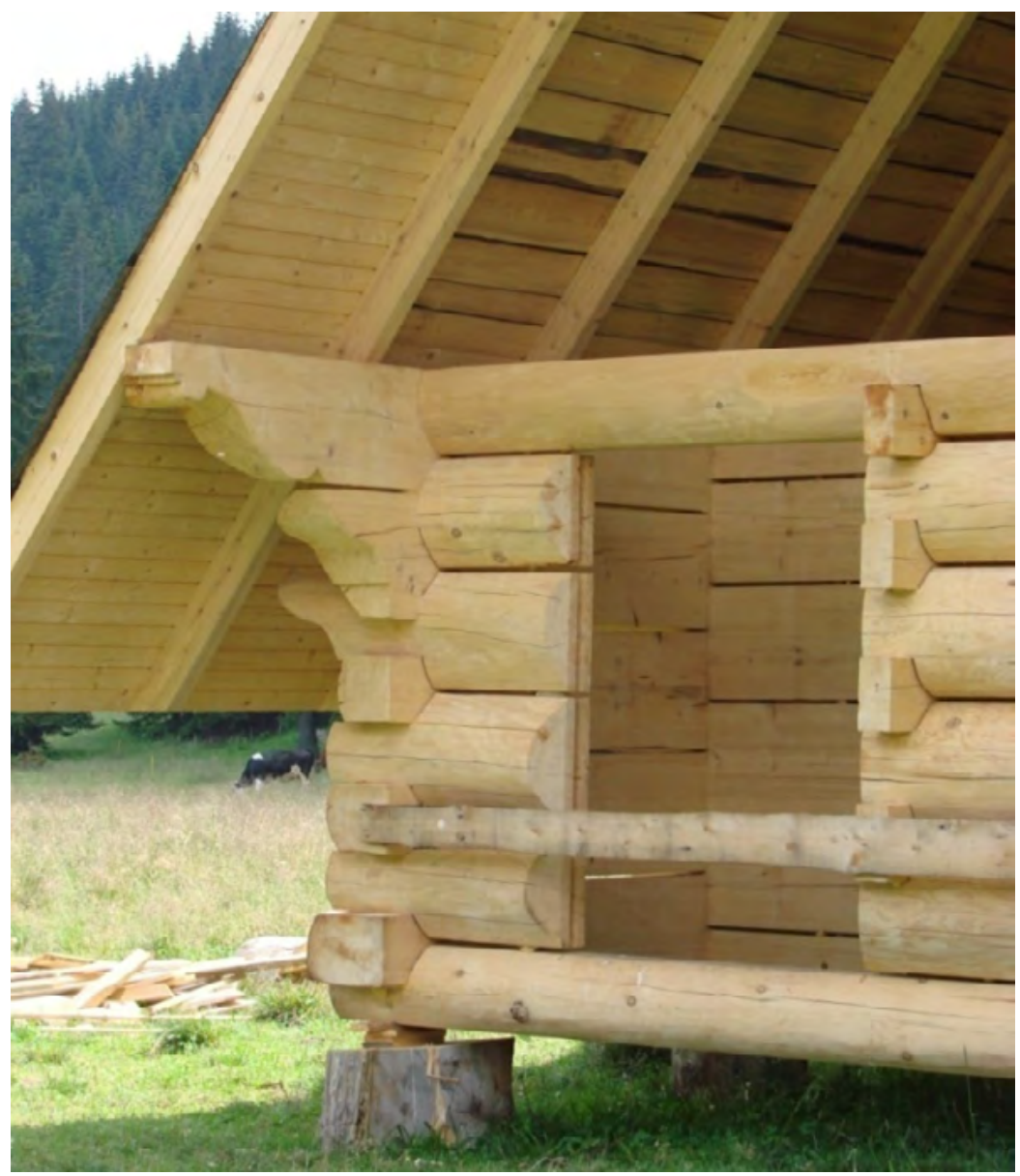

Ryc. 8. Tatry Polskie. Dolina Chochołowska. Ściana węgłowa. Szałas przygotowany pod układanie na tzw. „peckach", czyli na kamieniach, fot. Autor, 2014 rok

Fig. 8. Polish Tatras. Chochołowska Valley. The quake wall. A hut prepared for laying on the so-called "Pecki", that is on stones, photo: author, year 2014

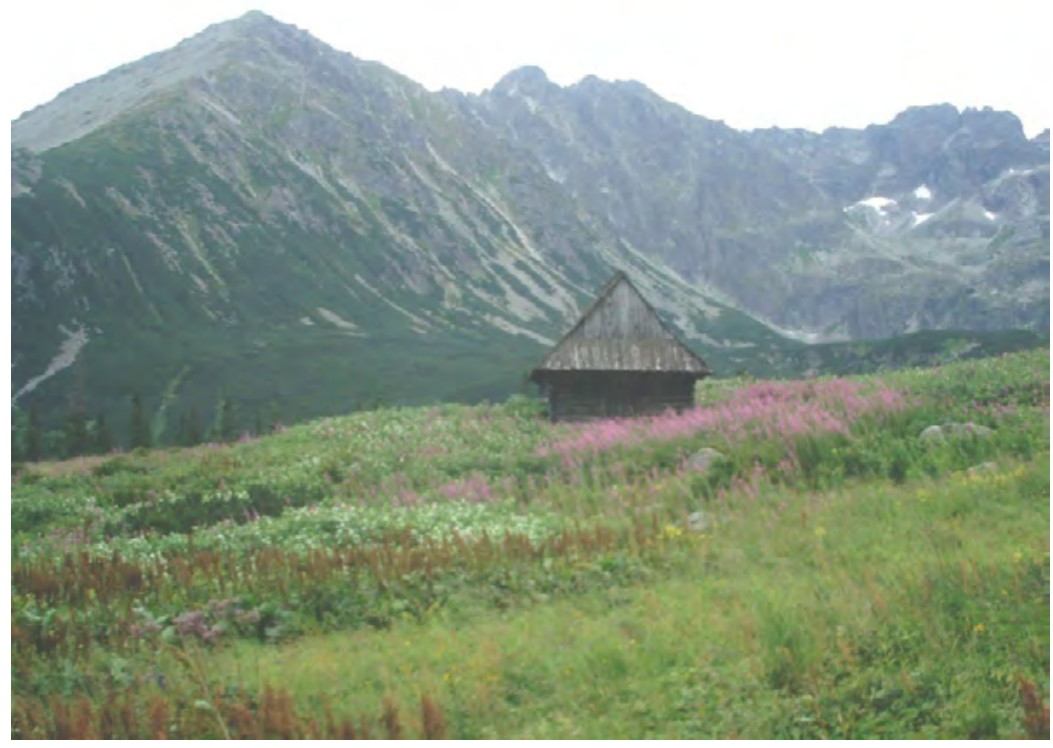

Ryc. 9. Tatry Polskie. Szałas na Hali Gąsienicowej. W tle od lewej: Żółta Turnia, Granaty, Kozi Wierch, fot. Autor, 2004 rok

Fig. 9. Polish Tatras. A hut at the glade Hala Gąsienicowa. In the background, from the left: Żółta Turnia, Granaty, Kozi Wierch, photo: author, year 2004 
Omawiając dalej konstrukcję ściany zewnętrznej szałasu, należy zwrócić uwagę, że różnicę pomiędzy ziemią i pierwszą belką wypełnia podwalina leżąca na kamieniach. Ten sposób budowania można zaobserwować w licznych ruinach szałasów położonych na trasie wiodącej na Turbacz przez Stare Wierchy. Na progu szałasu ustawia się tzw. słupce, wiążące otwór drzwiowy. Słupy mają na całej długości wpusty, wpuszczane są na czopy, krótkie elementy ściany, zamykające przestrzeń od węgła do słupów, zwane potocznie "sonikami”. Nadproże drzwi mocowane na słupach zwane jest oczepem, czyli po góralsku "ocapem". Stąd też widać zarys zmian nazewnictwa w konstrukcji rozwijanej przez stulecia.

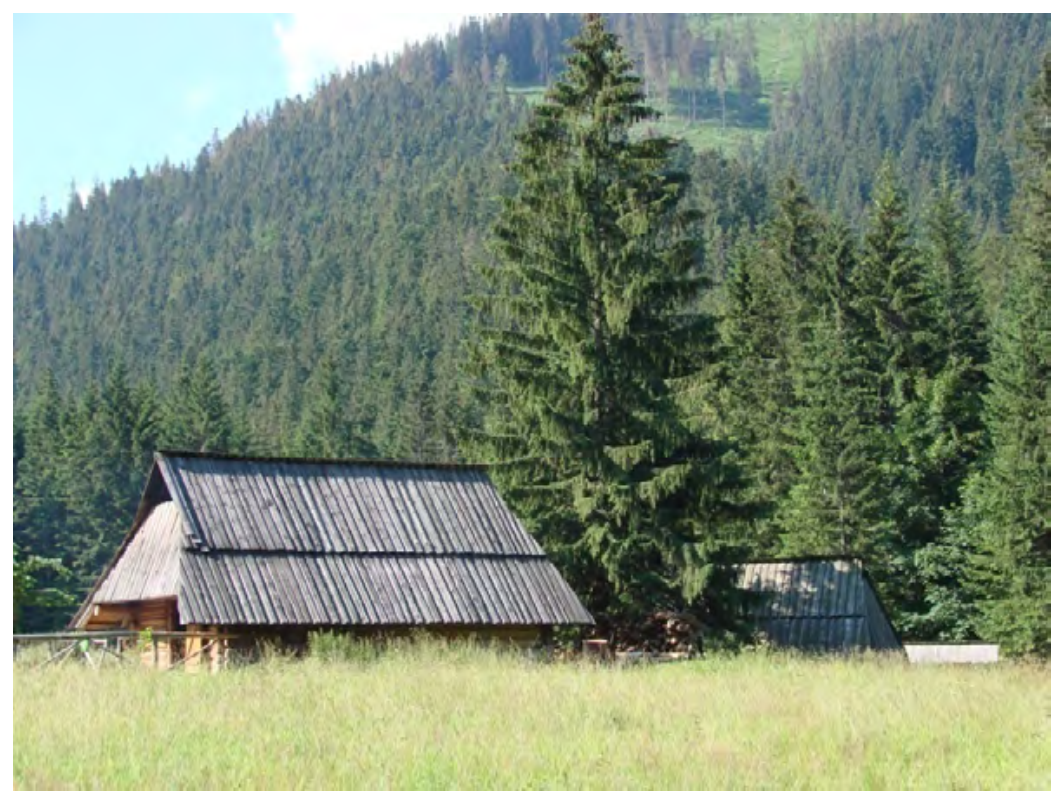

Ryc. 10. Tatry Polskie. Dolina Kościeliska. Szałasy pasterskie, fot. Autor, 2016 rok

Fig. 10. Polish Tatras. Kościeliska Valley. Shepherd's huts, photo: author, year 2016
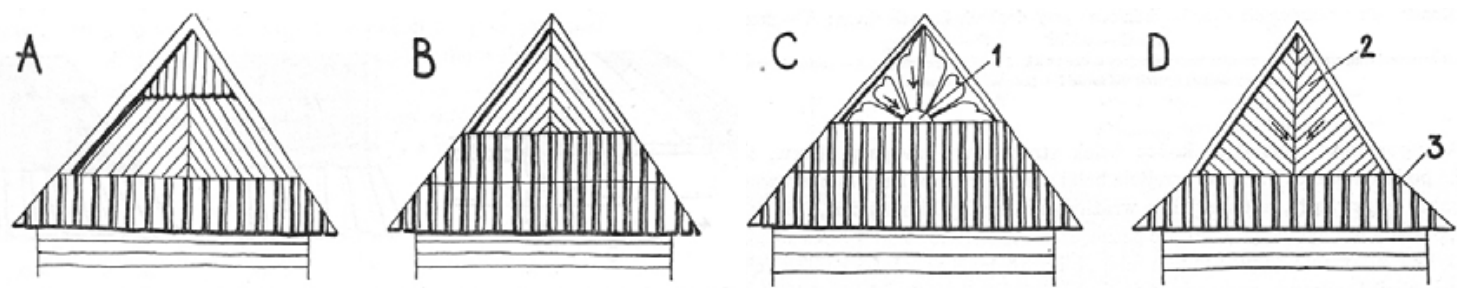

Ryc. 11. Tatry Polskie. Przykłady deskowania szczytów: A i B tradycyjne, C i D nowoczesne ulegajace szybkiemu odkształceniu na skutek opadów. 1 - Stoneczko, 2 - Jodełka sprowadzająca wodę, 3 - Zmiana nachylenia połaci okapu

Źródło: A. Rzymkowski M. Chowaniec, Ruralistyka - planowanie obszarów rolniczych i budownictwo wiejskie, Arkady, Warszawa 1972, s. 148.

Fig.11. Polish Tatras. Examples of gable formwork: $A$ and $B$ traditional, Modern $C$ and $D$, undergoing rapid deformation due to rainfall. 1 - Sunny, 2 - Herringbone bringing water, 3 - Change the slope of the eaves

Source: A. Rzymkowski M. Chowaniec, Ruralistyka - planning of agricultural areas and rural construction, Arkady, Warsaw 1972, p. 148

Dach szałasu pokrywano tzw. dranicami ${ }^{14}$, czyli deskami „dartymi" pozyskiwanymi z bezsęcznych pni drzew iglastych, głównie świerka i jodły przez ich rozszczepianie za pomocą klinów i ostruganie ośnikiem. Technika pokrywania dranicami była rozpowszechniona głównie na Podhalu i jest wytworem miejscowym. Zaletą dachów podbitych dranicami jest ich lekkość, szybkość i prostota pokrywania dużych połaci pod dużym kątem, a nawet pionowych ścian. Dranice nie nadają się jednak do powyginanych powierzchni. 
Innym znanym i popularnym systemem pokrycia szałasów był i jest gont drewniany, często łączony ze wspomnianymi dranicami. Gont wyrabia się z gatunków drzew iglastych przez promieniste rozklinowanie pnia. Układa się go w gęstym łaceniu lub na deskowaniu. Gont nadaje się do małych powierzchni o zmiennym kącie nachylenia. We wcześniejszych okresach według relacji rdzennych górali, do budowy zadaszeń stosowano na pokrycie szałasów bardzo prymitywne materiały - korę oraz słomę.

Istotnym zagadnieniem jest wpływ opadów na kształtowanie się formy architektonicznej dachu w obiekcie górskim, a pierwotnie w szałasach pasterskich. Duże ilości opadów atmosferycznych w środowisku górskim, których średnia roczna wynosi $1118 \mathrm{~mm}$, a średnia miesięczna 93,0 mm, wymaga wyraźnych osłon poziomych budynku.

Jest to jedno z podstawowych założeń, jeżeli chodzi o formowanie się dachów wiszących.

Obserwacja architektury środowiska Podhala potwierdza te tendencje. Szałas góralski posiadał silny okap dochodzący czasami z partii szczytowej do 2 a nawet 2,5 m.

Są to zależności formalne, które w kierunkach analizy i rozumowania niniejszego zagadnienia są istotne do podkreślenia, jako jeden z ważniejszych czynników oraz elementów kształtujących charakter architektury górskiej ${ }^{15}$.

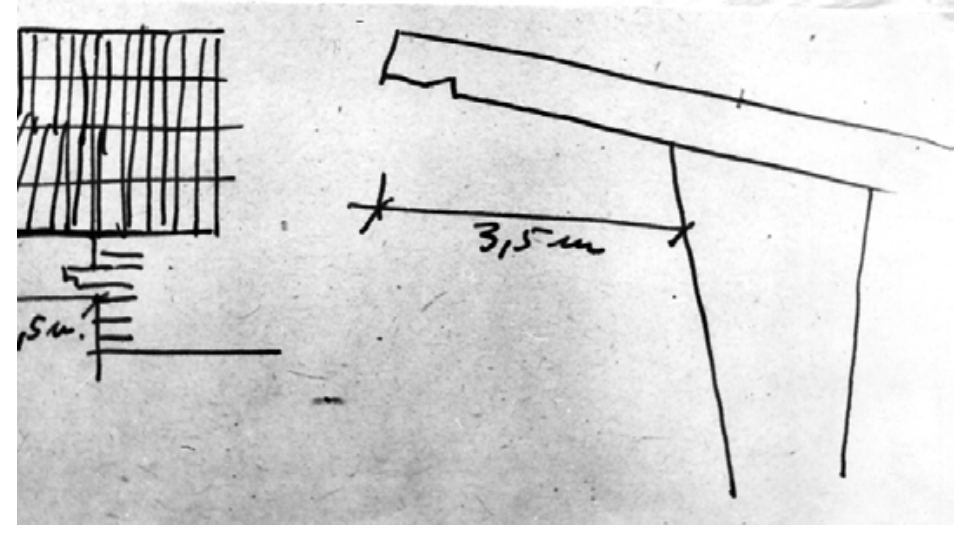

Ryc. 12. Tatry Polskie. Analiza kształtowania się dachu szałasu pasterskiego wg profesora Andrzeja Skoczka

Źródło: A. Skoczek, O niektórych parametrach architektonicznych kształtowania dachów wiszących w środowisku Podhala, maszynopis niepublikowany, Kraków 1961.

Fig. 12. Polish Tatras. Analysis of the shaping of the roof of a shepherd's hut by Professor Andrzej Skoczek

Source: A. Skoczek, About some architectural parameters of shaping hanging roofs in the Podhale environment, unpublished typescript, Kraków 1961

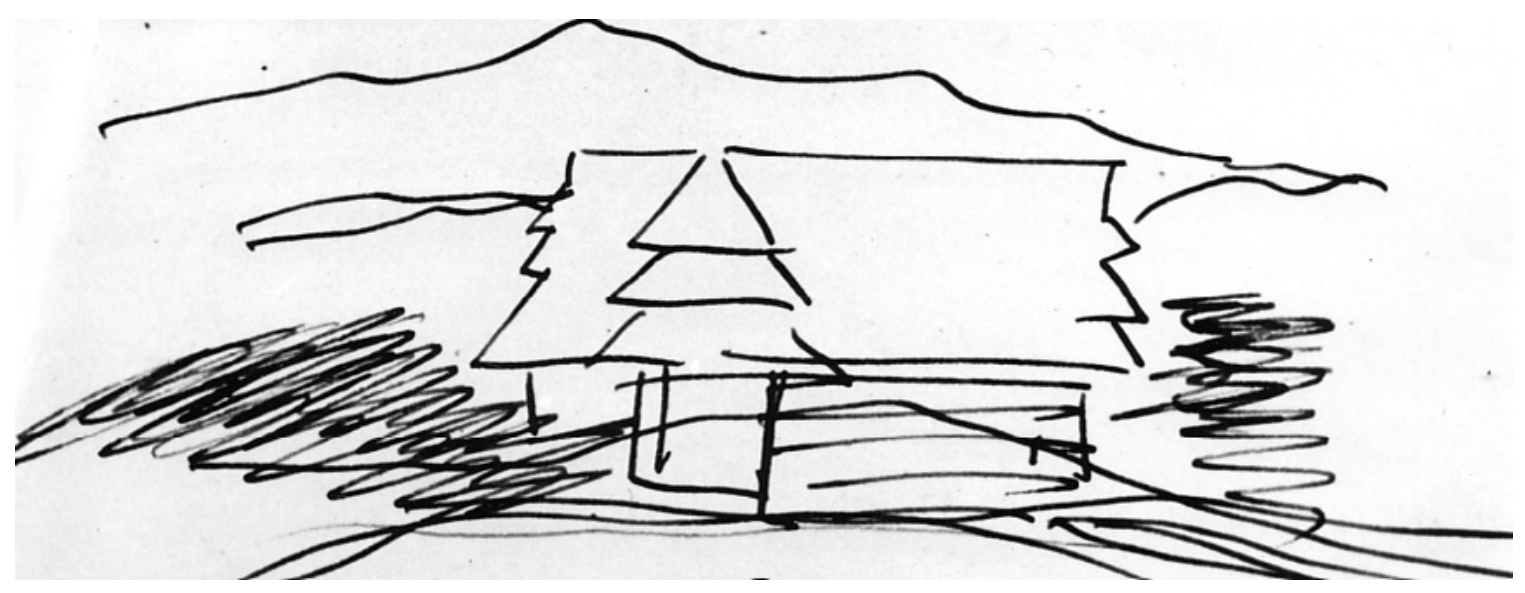

Ryc. 13. Andrzej Skoczek. Szkic dachu góralskiego. Tusz, czarny, karton

Źródło: A. Skoczek, O niektórych parametrach architektonicznych kształtowania dachów wiszących w środowisku Podhala, maszynopis niepublikowany, Kraków 1961.

Fig. 13. Andrzej Skoczek. Sketch of a highlander's roof. Ink, black, cardboard

Source: A. Skoczek, About some architectural parameters of shaping hanging roofs in the environment of Podhale, unpublished typescript, Kraków 1961.

15 Por. A. Skoczek, O niektórych parametrach architektonicznych kształtowania dachów wiszących w środowisku Podhala, maszynopis niepublikowany, Kraków 1961. 
Zespoły zniszczonej zabudowy szałasowej tworzą malownicze formy, stając się inspiracją dla malarzy, artystów, poetów oraz architektów w kierunku nowych trendów również we współczesnej architekturze. Poezja, mistycyzm oraz tajemnica tego typu rejonów tworzą nieodmiennie ciekawe zestawienia dla nowych form we współczesnym design.

Szałasy oprócz piękna immanentnego - własnego i niejako wewnętrznego, samego z siebie - są też cudem piękna kontekstu krajobrazowego - harmonijności z otaczającą naturą. Obserwując - szczęśliwie zachowane - szałasy na Hali Gąsienicowej, z dachami na tle Kościelca i Świnicy, widać wręcz identyczne proporcje i kąty nachylenia brył stworzonych przez naturę i kulturę, mimo że te ostatnie były projektowane wyłącznie z pobudek praktycznych, a nie estetycznych ${ }^{16}$.

Szałasy oglądane z dystansu i z wysoka, bardziej niż widziane z bliska - wpisują się organicznie w krajobraz, przypominając np. głazy nieregularnie rozrzucone przez siły natury - odłamy skalne lub wychodnie skaliste. Jeśli udało się im uniknąć bezsensownej zagłady, pozostają, jako świadkowie pozornie sielankowej, ale niełatwej dla górali epoki pasterstwa, a zarazem, jako ostańce najznakomitszej być może architektury bez architektów ${ }^{17}$.

W odróżnieniu od szałasów budowanych w Tatrach, inaczej kształtowano bryłę alpejskich odpowiedników pod Tatrami, czyli szałasów w Alpach. Zabudowa "niemiecka" posiada specyficzną konstrukcję i różni się w detalu. Można jednak stwierdzić, że i w Alpach pojawiały się konstrukcje zbliżone do typowo karpackich i architektura alpejska miała także wpływ na architekturę tatrzańską. Jedną z głównych różnic szałasów w Tatrach i Alpach jest kąt nachylenia połaci dachowej. Dachy szałasów tatrzańskich mają znacznie większy kąt, a szałasy alpejskie posiadają dachy prawie płaskie. Jest to różnica wynikająca z działania czynnika atmosferycznego, jakim jest wiatr ${ }^{18}$.
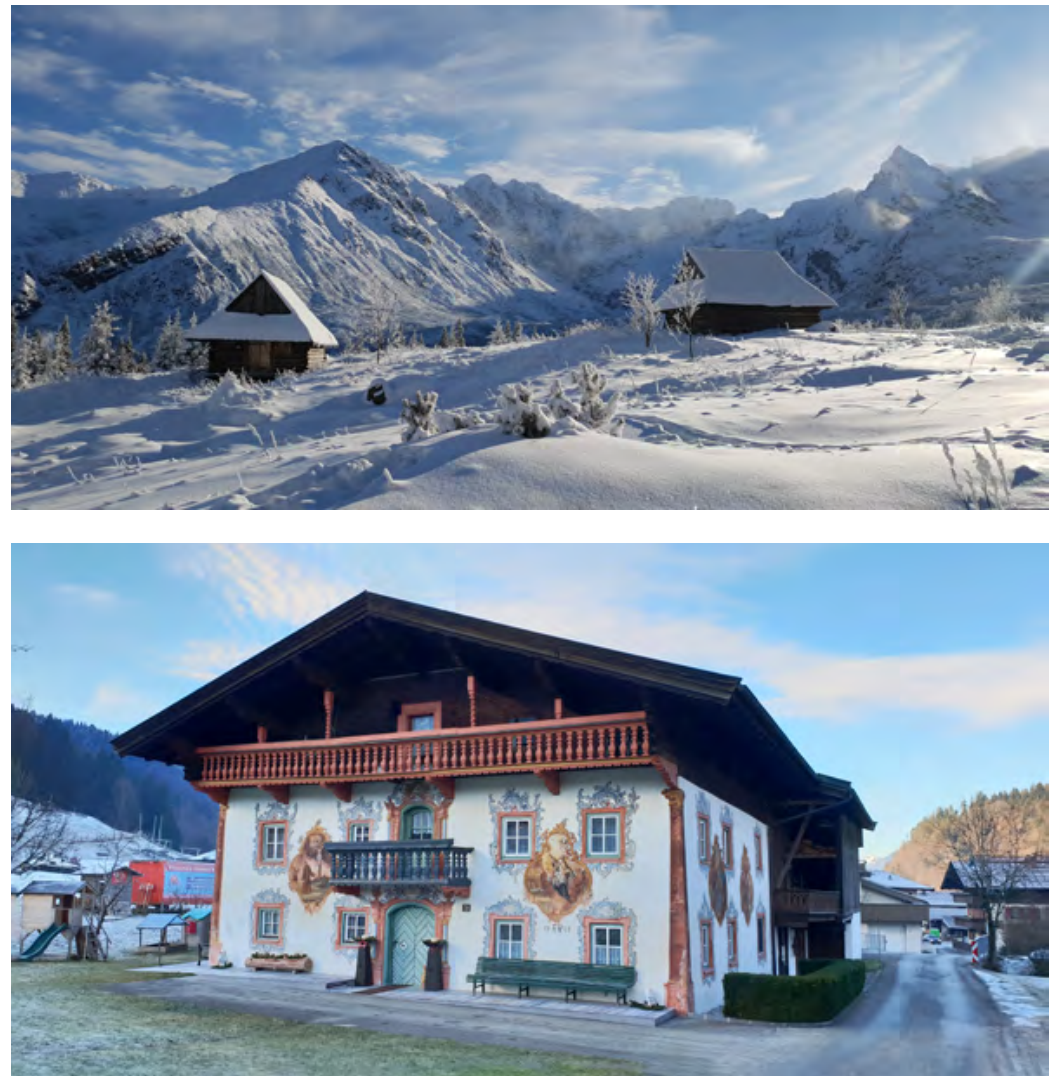

Ryc. 14. Tatry Polskie. Szałasy na Hali Gąsienicowej. Dzięki prostocie i regionalnej formie doskonale wpisują się w górski zimowy krajobraz. W tle od lewej do prawej: Kościelec, Świnica, fot. Autor, 2018 rok

Fig. 14. Polish Tatras. Shelters at Hala Gąsienicowa. Thanks to their simplicity and regional form, they fit perfectly in mountain winter landscape. In the background from left to right: Kościelec, Świnica, photo by the author, year 2018

Ryc. 15. Alpy. Walchsee, Austria. Architektura i zdobnictwo Tyrolu tzw. "laubsege architectour". Charakter dachu zaczerpnięty z tradycyjnych szałasów Alpejskich, fot. Autor, 2019 rok

Fig. 15. Alps. Walchsee, Austria. The architecture and ornaments of the socalled Tyrol "Laubsege architectour". The character of the roof taken from traditional Alpine huts, photo: author, year 2019

16 Znakomitym znawcą estetyki architektury góralskiej, i wielkim miłośnikiem szałasów tatrzańskich, był Włodzimierz Gruszczyński (1906-1973), profesor WA PK, czołowy przedstawiciel krakowskiej szkoły architektury regionalnej i architektury w krajobrazie. Inf. od śp. p. prof. W. Kosińskiego - w czasie konsultacji w 2015 roku.

17 Aluzja do wspaniałej książki-albumu Bernarda Rudofsky'ego nt. architektury samorodnej, wernakularnej. Por. B. Rudofsky, Architecture without Architects, Museum of Modern Art, New York 1966.

18 Por. P. Werner, Der Bergbauernhof, Callwey, München 1979, s. 97-103. 
W Tatrach przed podrywającym działaniem wiatru szałasy zabezpieczano poprzez strome dachy, często przedłużone do gruntu, a w Alpach pokrywano połać dachową kamieniami lub przytwierdzano linami. Na dachach stromych nie zalegał śnieg, wiejące wiatry dociskały więźbę do zrębu budynku. Wadą była mała powierzchnia szałasu spowodowana stromym dachem. W dachach rozłożystych - alpejskich - o konstrukcji ślęgowej, wiatr mógł powodować unoszenie dachu, w związku z tym stosowano głazy lub liny. Dzięki temu zabiegowi powierzchnia budynku była znacznie większa i przekształciła się w układ całoroczny, mieszkalny.

Kolejnymi atutami szałasów alpejskich jest zaskakująca szczelność ścian budynku i okien. W szałasach alpejskich można spędzać całą zimę. Szałasy tatrzańskie umożliwiają przebywanie od maja do września.

W Alpach przetrwały dachy z konstrukcją sochową, dominujące w Tatrach w XIX w. i zostały przekształcone w późniejszym okresie w półsochy, a pod koniec XIX w. wyparły je obecne dachy krokwiowe ${ }^{19}$.

Tyrolskie budynki charakteryzuje również budowa na zrąb. Różnice pomiędzy szałasami tatrzańskimi i alpejskimi wynikają przede wszystkim z warunków przyrodniczych, w dalszej części z formy i funkcji, a także potrzeb komfortu i bytowania przez ich użytkowników, poszukujących różnych rozwiązań architektonicznych i praktycznych. W Tatrach kształtuje się forma poddana bytowaniu w trudnych warunkach, a w Alpach forma praktyczna podążająca za funkcją, przeznaczona do przebywania dłuższego z korzystniejszymi rozwiązaniami przestrzennymi wewnątrz budynku.

\section{Kaplice}

Kolejnym plastycznym rodzajem architektury regionalnej w górach są obiekty sakralne. Kapliczki, kaplice oraz świątynie lokalizowano najczęściej w miejscach szczególnych wydarzeń lub jako miejsca kultu i religii.

Często były one wznoszone, jako pustelnie z racji możliwości „zagubienia w naturze”20, jak np. Klasztor Sióstr Albertynek w lesie przy drodze na Kalatówki w TPN od strony Kuźnic.

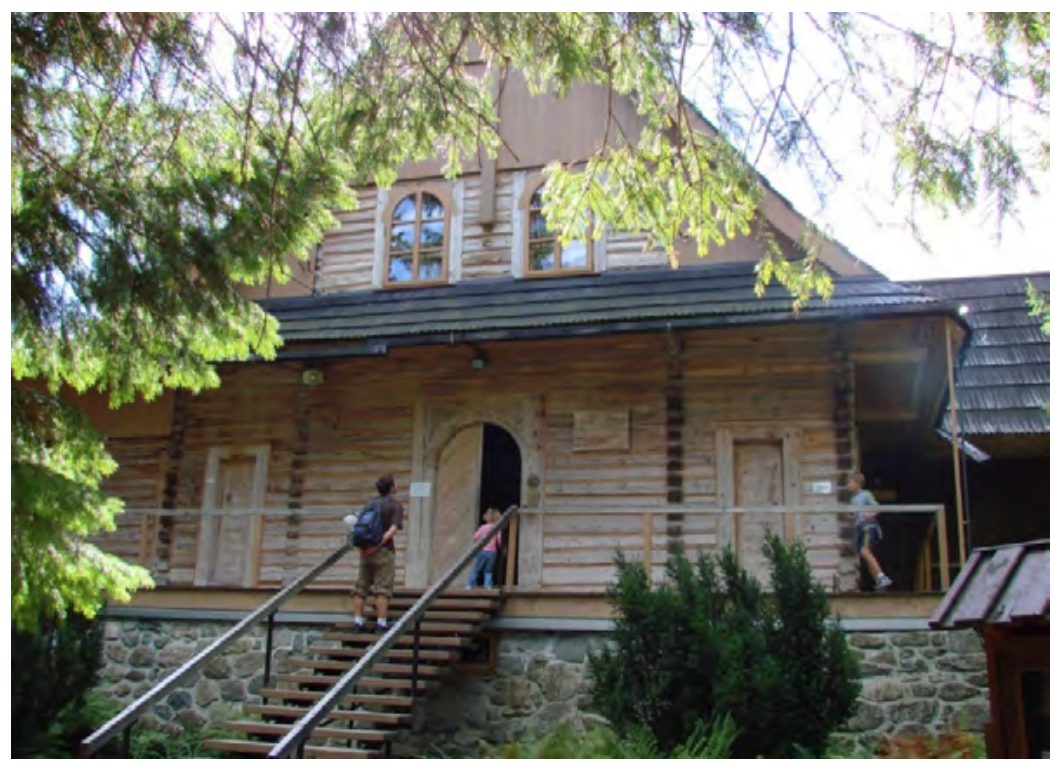

Ryc. 16. Tatry Polskie. Klasztor Sióstr Albertynek na Kalatówkach, fot. Autor, 2006 rok

Fig.16. Polish Tatras. Monastery of the Albertine Sisters in Kalatówki, photo: author, year 2006

Obiekty religijne stanowią nieodłączny element pasm górskich. Można je spotkać na dużych i małych wysokościach, jako murowane i drewniane budynki, oraz proste bryły ułożone z kamieni czy mocowane przy drzewie, często spotykane w polskich górach - Bieszczadach, Gorcach, Beskidach i Tatrach.

Obiekty sakralne projektowane są przede wszystkim dla danego miejsca, z uwzględnieniem standardu estetycznego, wzorowo wykonane są ozdobą krajobrazów. Wzbogacają aspekt duchowych doznań w wysokich górach. 
W Tatrach oraz w całych Karpatach podczas wędrówek spotykamy wiele kaplic i kapliczek. Poświęcone są one żołnierzom, wspinaczom, turystom, a także wielu znakomitym ludziom, którzy oddali się sprawie niepodległości i przyczynili do popularyzacji etycznego charakteru współczesnej eksploracji i kultury górskiej; Przykładem takiej małej architektury może być kaplica pod Osterwą (w słowackiej części Tatr). Jest to sanktuarium poświęcone wspinaczom, którzy swą pasję okupili śmiercią.

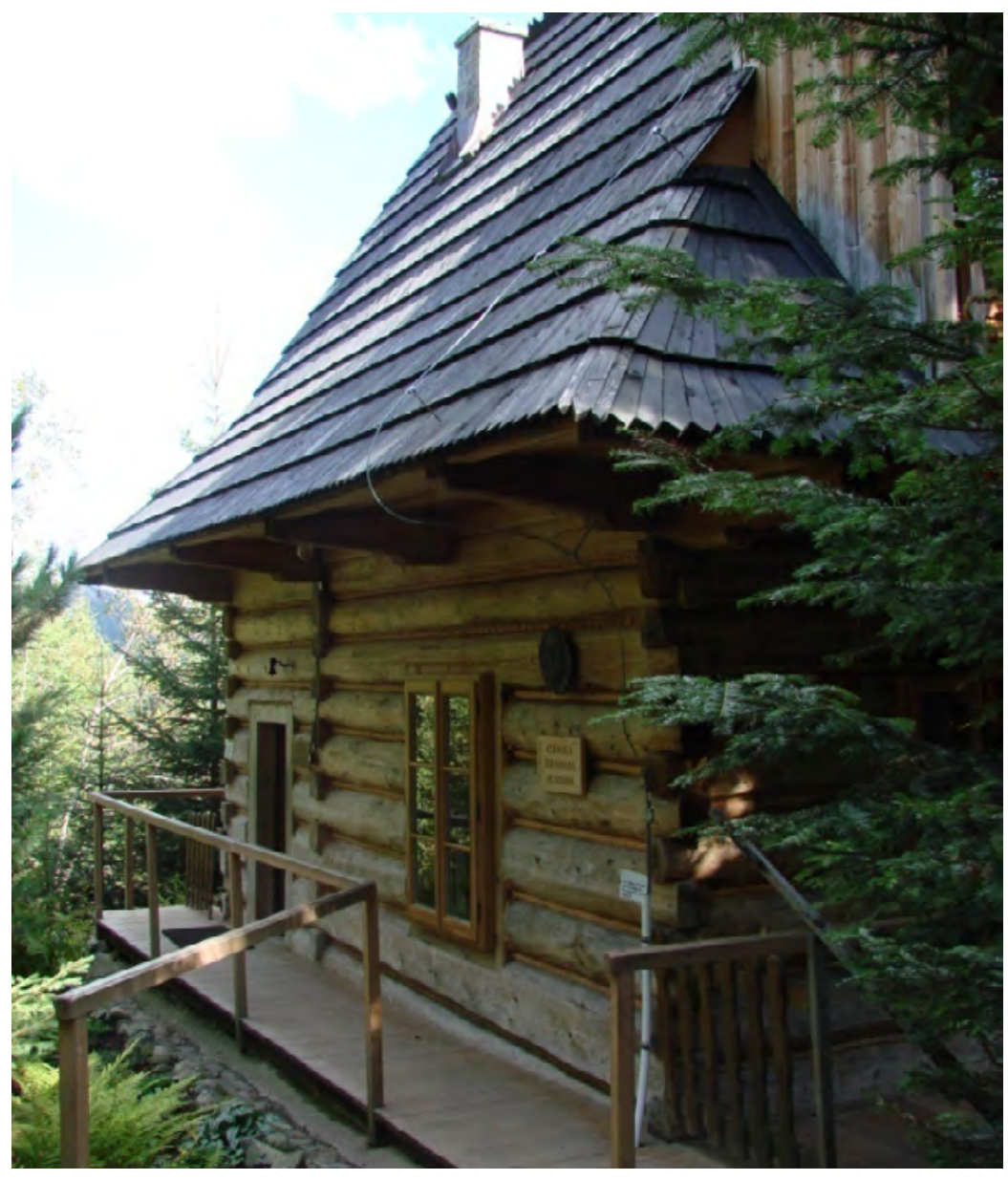

Ryc. 17. Tatry Polskie. Klasztor Sióstr Albertynek - pustelnia Brata Alberta, fot. Autor, 2006 rok

Fig. 17. Polish Tatras. Monastery of the Albertine Sisters - Brother Albert's hermitage, photo: author, year 2006

\section{Kuźnice - pionierski rozwój Podtatrza}

Kuźnice stały się od połowy XVIII w. osadą, która zaczęła kształtować oblicze Tatr w odniesieniu do Zakopanego stawiającego pierwsze kroki w aspekcie rozwoju formy osady. W obszarze Kuźnic powstawały niewielkie ośrodki przemysłowe jak huty i osady hamerskie, wykorzystujące naturalne ukształtowanie terenu oraz jego morfologię i hydrologię do napędzania infrastruktury technicznej. Intensywna ewolucja industrialna spowodowała, że do Kuźnic oraz do okolicznych miejscowości m.in. wsi Zakopane zaczęli przybywać pracownicy wielonarodowościowego pochodzenia zabudowę terenu Podtatrza i dodając inne elementy oraz detale. Było to urzeczywistnienie wizji przestrzeni mieszkalnych w rejonach podgórskich oraz założeń jak zabudowa dworska m.in. Homolaczów, którzy w XIX dzięki własnym inwestycjom intensywnie dźwignęli przemył hutniczy ${ }^{21}$. 
Kuźnice zmieniały swój wizerunek wpływając na rejon i przyciągając inwestorów oraz ludzi szukających zatrudnienia. Eksploracja Tatr zaczęła niekorzystnie wpływać na stan zadrzewienia i naturalny charakter obszarów leśnych, ponieważ drzewo było paliwem do napędzania wielkich hutniczych pieców.

Trudności powodowały stopniowy upadek Kuźnic. Jednocześnie rosło zapotrzebowanie na materiały papiernicze a inwestorzy upatrywali w lasach tatrzańskich ratunek dla swoich interesów. Korzystne warunki przyrodnicze w Tatrach sprzyjały wzrostowi drzew, co przełożyło się na jakość drewna i jego popularność.

Huty hamerskie oddawały przestrzeń fabrykom celulozy w XIX w., a w kolejnych latach obiektom papierni. W tym okresie poprzez zapotrzebowanie na zwiększoną moc zakładów układ Kuźnic wydłużył się obejmując Zakopane.

Kuźnice stały się pierwszym na Podhalu miejscem, które skupiało różnojęzyczne społeczeństwo. Dzięki napływowi mieszkańców rozwijało się także Zakopane. Kuźnice około 1848 stały się osadą większą niż sąsiadująca miejscowość. Należy wspomnieć fakt, że odmiennie kształtowały się te dwie lokalizacje. Zakopane było ubogą osadą góralską, nękaną częstym nieurodzajem. Mieszkańcy szukali zatrudnienia w kopalniach tzw. "baniach” i hutach czyli „hamrach”. W miarę upadku form przemysłowych wzrastał ruch turystyczny i leczniczy w Kuźnicach, gdzie od 1840 r. zlokalizowano urządzenia do hydroterapii. Ludwik Zejszner opisując Tatry, dużo uwagi poświęca lecznictwu rozwijającemu się w tatrzańskich osadach hutniczych, planując założenie uzdrowiska w Zakopanem ${ }^{22}$. Zakopane w tym okresie nie było popularną miejscowością, szukano tam noclegów tylko wówczas gdy brakło miejsca przy Kuźnicach. Duża bliskość hal skąd czerpano dla kuracjuszy żentycę i kosodrzewinę, czyste strumienie górskie i żużel do zabiegów, doskonała aprowizacja i wygodne kwatery składały się na komfortowe warunki mieszkania zbliżone do warunków w uzdrowiskach zachodnich. Kuźnice stanowiły w okresie największego rozkwitu ośrodek kulturalny na Podtatrzu gdzie zlokalizowano teatr amatorski, orkiestrę, gospodę oraz wytyczono pierwsze ścieżki rekreacyjne m.in. na Nosal. W 1875 r. napływ kuracjuszy skłonił zarządców do budowy w Kuźnicach zakładu leczniczego, którego program obejmował część zabiegową i hotelową. W 1876 Komisja balneologiczna akademicka w Krakowie otrzymała informację o realizacji zakładu żentyczno-kumysowego.

Wpływ czynników zewnętrznych w kotlinie zakopiańskiej uwidocznił się przede wszystkim w zakresie budownictwa i jego urbanistyki. Na tereny Podtatrza zaczęły przenikać nowe, różnorodne formy mające za zadanie zaspokoić potrzeby wizerunkowe ludności napływowej i kształtować świeże oblicze Zakopanego - uzdrowiska. Sprzyjała temu rozproszona forma wioski. Zakopane formalnie stało się stacją klimatyczną, która zaczęła wypierać wiejskie kwatery będące jedynym oparciem dla osób przybywających w porze letniej. Jednak Zakopane nie stwarzało dobrych warunków leczniczych. Warunki te były dalekie od tych, jakie kształtowały polskie uzdrowiska, nie wspominając renomowanych zagranicznych miejscowości kuracyjnych w Alpach. Niemniej jednak prymityw ten zadowalał licznie zjeżdżających letników i entuzjastów przyrody. Powiększała się grupa osób przybywających w celach zdrowotnych, bywalców uzdrowisk. Naprzeciw wymogom tej grupy wyszło Tatrzańskie Towarzystwo, które podjęło budowę infrastruktury uzdrowiskowej i turystycznej Zakopanego, na przekór obojętności autochtonów. Towarzystwo własnymi środkami rozpoczęło naprawę dróg, mostów oraz uzupełnianie infrastruktury administracyjnej i miejskiej, podnosząc rangę i status Zakopanego.

Rozpoczął się inteligencki i pionierski podbój Tatr tzw. „piewców gór”. Młodopolska bohema wyjeżdżająca z Krakowa do Zakopanego nowo zrealizowaną koleją, śmielej korzystała z usług przewodników Podhala m.in. słynnego Bartłomieja Obrochty, zwanego Bartusiem ${ }^{23}$. W warunkach tych przejazdy do Zakopanego nabierały charakteru przygody, rozgrywającej się na tle monumentalnej scenerii w oderwaniu od komfortu miejskiego życia. Ilość odbiorców tych przeżyć była zawężona do wąskiej elity. Rosło zapotrzebowanie na schroniska i schrony górskie, a także ekskluzywne lokalizacje wypoczynkowe. Rozpoczęto adaptację tradycyjnych szałasów góralskich z dachami przyzbowymi i pełną zabudową ścian węgłowych na obiekty całoroczne. W okresie zimowym szałasy ogrzewano tradycyjnymi piecami kamiennymi lub paleniskami, a bardziej nowoczesne wyposażano w tzw. wyględy, czyli dodatkowe przestrzenie do spania nad wejściem, oraz żeliwne piece grzewcze ${ }^{24}$. O degradacji

22 Por. J. Konieczniak, Encyklopedia schronisk tatrzańskich, Oficyna Wydawnicza "Wierchy”, Kraków 2010.

23 Por. S. Witkiewicz, Na przełęczy, Wydawnictwo LTW, reprint Warszawa 1891

24 Por. M. Kulig, Architektura tatrzańskich schronisk górskich Polskiego Towarzystwa Tatrzańskiego w dwudziestoleciu międzywojennym Wydawnictwo Neriton, Warszawa 2003. 
i przeróbce dóbr kulturowych pisał Walery Eljasz Radzikowski - cel był zawsze ten sam i dotyczył warunków stwarzających nowe potrzeby, dla których poświęcano wartości historyczne widoczne w regionalizmie ${ }^{25}$.

\section{Podsumowanie}

Tradycyjna architektura ewoluowała, poddana nowym konceptom współczesnego użytkownika. Istotne zmiany mające podstawę w budownictwie stałym upodobniły obiekty do form współczesnych tworząc $z$ nich wielosezonowe, neoregionalne i nowoczesne budynki.

Szałasy oglądane z dystansu, bardziej niż z bliska, doskonale wpisują się w krajobraz gór, przypominając głazy rozrzucone z rozmysłem w dolinach lub u stóp wzniesień. Jeżeli uniknęły zagłady, pozostały jako świadkowie "sielankowej" i niełatwej epoki pasterstwa oraz symbole znakomitej architektury wernakularnej - architektury bez architektów.

Na Podtatrzu możliwości osiedlenia zostały w pełni wykorzystane mimo niesprzyjających warunków przyrodniczych. Fala osadnictwa stałego dotarła na znacznej przestrzeni do podnóża Tatr. Na tym charakterystycznym obszarze stanowiącym formę przejściową, proces osadniczy postępuje, stanowiąc po części zanikającą formę ewolucji osadnictwa pasterskiego i stałego a w dalszej części żywiołową ekspansję osadnictwa o funkcji rekreacyjnej. Formy osadnictwa mają funkcję mieszaną, rozwijają się najczęściej w rejonach atrakcyjnych o dobrych warunkach komunikacyjnych. Doskonalszym rozwiązaniem jest utrzymanie nawiązania do tradycyjnych wartości i utrzymania ładu urbanistycznego Podtatrza. Należy zachować czystość konstrukcji architektury góralskiej, jednak tego typu starania wpływają na zagubienie naturalnej tożsamości architektury górskiej, charakterystycznej dla naszego regionu. Głównie w wysokich partiach gór odnaleźć można prawdziwą wartość tradycyjnej architektury tatrzańskiej, obecna intensywna eksploracja stwarza zagrożenia dla utrzymania tożsamości tych obiektów. W miejsce dawnego wyrafinowanego krajobrazowego skromnego regionalizmu estetycznego adresowanego do ludzi gór, dochodzą do głosu priorytety turystyki dla hedonistów, a w estetyce: odrzucenie tradycji na rzecz nowoczesności oraz sprowadzania wyglądu do poziomu komercyjnego gustu szerokiego grona odbiorców. Kształtowanie architektury Podtatrza, nie będącej stylem - jest trudne.

Prof. Włodzimierz Gruszczyński twierdził, że "styl jest osiągnięciem wartości nieprzemijających" to "wyraz zbiorowej duszy"26. Natomiast prognozowanie dalszego jej rozwoju nieprzewidywalne. Jedynym możliwym rozwiązaniem jest zrównoważony rozwój wybranych regionów na bazie tradycji zmierzającej do nowoczesności.

\section{Bibliografia}

[1] Buszko Józef, Wielka historia polski tom 8 - Od niewoli do niepodległości, Oficyna Wydawnicza Fogra, Kraków 2000.

[2] Edoardo Gellner, Alte Bauernhäuser in den Dolomiten, Callwey, München 1980.

[3] Eljasz Walery, Szkice z podróży w Tatry, reprint wydania z 1874 roku, nr egz. 695, Krajowa Agencja Wydawnicza, Kraków 1990.

[4] Jagiełło Michał, Listy o stylu zakopiańskim 1892-1912 wokół Stanisława Witkiewicza, Wydawnictwo Literackie, Kraków 1979.

[5] Konieczniak Jan, Encyklopedia schronisk tatrzańskich, Oficyna Wydawnicza "Wierchy", Kraków 2010.

[6] Kulig Marzena, Architektura tatrzańskich schronisk górskich Polskiego Towarzystwa Tatrzańskiego w dwudziestoleciu międzywojennym, Wydawnictwo Neriton, Warszawa 2003.

[7] Radwańska - Paryska Zofia, Paryski Witold Henryk, Wielka encyklopedia tatrzańska, wyd. „Wydawnictwo Górskie", Poronin 1995

[8] Rzymkowski Andrzej, Chowaniec Maciej, Ruralistyka - planowanie obszarów rolniczych i budownictwo wiejskie, Arkady, Warszawa 1972.

[9] Skoczek Andrzej, O niektórych parametrach architektonicznych kształtowania dachów wiszących w środowisku Podhala, maszynopis niepublikowany, Kraków 1961.

25 Por. M. Jagiełło, Listy o stylu zakopiańskim 1892 - 1912 wokół Stanisława Witkiewicza, Wydawnictwo Literackie, Kraków 1979.

26 Por. T. Węcławowicz, A. Jankowska-Marzec, Architektura wzruszeniowa Włodzimierza Gruszczyńskiego, Towarzystwo Naukowe "Societas Vistulana", Kraków 1999. 
[10] Śmiałowski Rudolf, Architektura i budownictwo pasterskie w Tatrach Polskich, PWN, Kraków 1959.

[11] Szafer Tadeusz Przemysław, Tatrzańskie szałasy pasterskie, Wydawnictwo Zakład Historii Urbanistyki i Architektury PAN, Warszawa 1961.

[12] Teka Architektury Współczesnej Ziem Górskich, praca zbiorowa pod redakcją T.P. Szafera, Oficyna Wydawnicza Sezon, Kraków 1993.

[13] Tłoczek Ignacy, Polskie budownictwo drewniane, Zakład Narodowy im. Ossolińskich, Warszawa 1980.

[14] Werner Paul, Der Bergbauernhof, Callwey, München 1979.

[15] Węcławowicz Tadeusz, Jankowska-Marzec Agnieszka, Architektura wzruszeniowa Włodzimierza Gruszczyńskiego, Towarzystwo Naukowe "Societas Vistulana”, Kraków 1999.

[16] Witkiewicz Stanisław, Na przełęczy, Wydawnictwo LTW, reprint Warszawa 1891.

[17] Witruwiusz, O architekturze ksiąg dziesięć, wyd. Pruszyński i spółka, Warszawa 2004.

\section{Pioneering exploration of the mountains expressed through architecture}

Summary: The study is designed to organize the knowledge on development of mountain architecture. It covers a time period, drawn from pioneering discoveries in the architecture and landscape of the mountains. In the thematic aspect, analized problem in the subject of tourism and shaping mountain facilities on selected examples. Included issues related to construction and the use of native materials depending on the location, as well as factors such as climate and the tradition of the place. The importance of nature and the attempt to answer how to shape architecture without interfering with the natural environment and linking nature and buildings with each other were also emphasized. Changes in architectural forms were also indicated, as well as the scope of the influence of cultural diversity and drawing on patterns.

During the analysis of the topic, the author studied and collected materials directly and indirectly related to the topic. The works of mountain architecture mentioned in the text were analyzed, as well as their history and historical development. The point was presented on the basis of issues including development, as well as sections of thematic, territorial and time ranges, characterizing individual stages of the development of mountain architecture from the beginning of the existence of the studied mountain structures shaped by the culture of gathering and pastoralism to a detailed analysis prepared on the basis of mountain architecture of the $19^{\text {th }}$ and $20^{\text {th }}$ centuries.

First, there was wood, stones, earth - the basic building blocks. Mountain architecture is often demanding, monumental with a shape characteristic of the landform, less for a regional nature, although derived from it, but also objects that create the nature and character of the place, the so-called "Genius loci". The search for fantasy as well as unique beauty - all this is an extension of the fact that mountain architecture is not only a craft with narrowly delineated borders, but a light, creative and uninhibited art. In orderly contrast, the shape is subject is to the opposite of chaos, to the control of order at the edge of the design process. In buildings which characterized by a contrast to the surroundings - geometry and form, as well as structure are the way to non-accidental architecture in difficult conditions. Architecture hidden in the field, introverted, closed in the world that frees the recipient from the daily disorder. It is pure pioneering work of architects without architecture creating objects from imitation, such as huts and typical mountain shelters based on pure regionalism.

In mountain architecture, you can agree to three basic varieties:

- architecture from imitation - mimesis - the principle of creative imitation,

- architecture - harmonic, unique patterns,

- architecture in conscious contrast.

Keywords: mountain architecture, Tatra Mountains, Zakopane, Kuznice, highlander hut, town 